\title{
Effect of Maize/Haricot Bean Intercropping on Soil Fertility Improvement under Different Tied Ridges and Planting Methods, Southeast Ethiopia
}

\author{
Siraj Beshir ${ }^{*}$, Jemal Abdulkerim² \\ ${ }^{1}$ Department of Natural Resource Management, College of Agriculture and Natural Resources, Madda Walabu \\ University, Bale Robe, Ethiopia \\ ${ }^{2}$ Plant Science, College of Agriculture and Natural Resources, Madda Walabu University, Bale Robe, Ethiopia \\ Email: *sirajnrm@gmail.com
}

How to cite this paper: Beshir, S. and Abdulkerim, J. (2017) Effect of Maize/Haricot Bean Intercropping on Soil Fertility Improvement under Different Tied Ridges and Planting Methods, Southeast Ethiopia. Journal of Geoscience and Environment Protection, 5, 63-70.

https://doi.org/10.4236/gep.2017.58007

Received: June 8, 2017

Accepted: July 30, 2017

Published: August 2, 2017

Copyright $\odot 2017$ by authors and Scientific Research Publishing Inc. This work is licensed under the Creative Commons Attribution International License (CC BY 4.0).

http://creativecommons.org/licenses/by/4.0/

(c) (i) Open Access

\begin{abstract}
Mono cropping is the dominant factor influencing plant nutrient uptake and loss of soil quality in Ethiopia whereas intercropping of cereal/legume has positive environmental qualities. Likewise drought and moisture stress condition is widely expanding from all direction to the center of the country. Therefore, the objective of this research was to evaluate influence of planting methods, tied ridge and cropping system on different soil chemical properties in case of Madda Walabu district, Southeast Ethiopia. It was undertaken at Bidire from March 2016 to January, 2017. In this experiment, one maize variety (Melkassa 2) and one haricot bean variety (Nasir) were used. Treatments include open end and closed end tied ridge; sole cropping and intercropping; and in furrow, on ridge and flat bed planting. Each treatment has been triplicate and the experiment plots were laid out in randomized complete block design. Intercropping of maize-haricot bean with tied ridge and planting methods were highly influenced soil $\mathrm{pH}$, exchangeable potassium, available phosphorous, soil organic matter and total soil nitrogen. Generally, the use of intercropping and closed end tied ridge in combination with in furrow planting significantly increased $\left(\mathrm{p}_{0.05}\right)$ soil fertility in the system, which could be promising for sustainable improvement of crop production and productivity for semi arid areas of Bale zone.
\end{abstract}

\section{Keywords}

Tied Ridge, Intercropping, Planting Methods 


\section{Introduction}

Soil degradation is expressed in quality and quantity of soil nutrients, physical and biological soil characteristics which is linked to stagnation and decline in yields in the most intensive agriculture [1]. The decline in these soil properties is interconnected to the improper use of inorganic fertilizer and lack of organic fertilization, practices that are now widespread in the most intensive agriculture in developing countries [2]. For instance, repeated-application of urea under crop production and soil fertility improvement program is not only causing nutrient imbalances, but also negatively affecting the physical and biological properties of the soils [3]. Thus under common nitrogen fertilizer applications, natural nutrient cycling, microbial biomass, enzymatic activity and water-holding capacity of the soil are dramatically reduced whereas acidification and nitrate accumulation in water bodies increases [2] [4].

Therefore, by considering the environmental problems associated with current cropping systems in Ethiopia particularly Oromia region, Bale Zone, it seems reasonable to continue research on the possibilities of growing cereal-legumes intercropping which will rival the current mono cropping systems. Further studies by [5] indicated that failure by smallholder farmers in Bale zone of Oromia region to implement intercropping system and lack of plant nutrients due continuous mono cropping nutrients uptake, nutrients leaching and soil erosion are the principal causes of low agricultural productivity and food insecurity in Ethiopia.

Cereal/legumes cropping system is advanced as one of the integrated soil fertility management practices consisting of growing two or more crops in the same space at the same time, which have been practiced over the years and achieved the soil fertility restorations and crops yield in agriculture [6]. Likewise in Ethiopia Highland growing of several crops in association or in mixtures mainly being cereal and legumes is not new a technology for soil fertility improvement and reducing evapotranspiration from the field [7]. A study by [8] noted the decline in soil fertility and moisture stress being the major limitation to crops yield in cereal based cropping systems in Eastern and Southern Africa.

Similarly, due to soil and crop moisture stresses are dramatically expending in the country moisture retention structures and planting methods plays a vital role for successful and sustainable crop production. Therefore, planting crops using insitu moisture conservation reduces problems of soil moisture stress. Thus different tied ridge and planting methods with spaced fixed distance apart to form a series of micro catchment basin created to catch and hold rainwater, minimizing surface runoff, improve downward infiltration of water [9]. Therefore the objective of this research was to evaluate influence of planting methods, tied ridge and cropping system on different soil chemical properties.

\section{Materials and Methods}

\subsection{Description of the Study Area}

Madda walabu district located between $5^{\circ} 45^{\prime} \mathrm{N}, 39^{\circ} 40^{\prime} \mathrm{E}$ latitude and longitude 
respectively. It is one of the districts in the Oromia Region of Ethiopia. In addition it is bounded by Guji zone in the West and south, Gura dhamole district and Delo Mena district in the East, Harena Buluk district in the Northwest. The administrative center of the district is Bidire [10].

Thus, the district is located in the south Western parts of the Bale zone. The area of the district leads the zone to have a share of 12.93 percent from the total area of the zone $\left(69,661 \mathrm{~km}^{2}\right)$. The district has a distance of $200 \mathrm{~km}$ from zone capital called Robe and $630 \mathrm{~km}$ from Finfine. The mean annual temperature of the district is $30^{\circ} \mathrm{C}$. The lowest temperature is $20^{\circ} \mathrm{C}$ and highest is $40^{\circ} \mathrm{C}$ respectively. The mean annual rainfall is $600 \mathrm{~mm}$ whereas the lowest and highest rainfall is $400 \mathrm{~mm}$ and $800 \mathrm{~mm}$ respectively. Madda Walabu District have two major cropping season which is known as Maher and Belg. Cereals, pulses, Oilseed, fruit, vegetables and spice are the known crop grown in the District. Cereals are the main crops that are produced during Maher season and pulses, oil seed, vegetables, fruit, and spices are followed [10].

\subsection{Plot Soil Sampling and Analysis}

Sampling for soil $\mathrm{pH}$, organic carbon, total nitrogen available phosphorous and Potassium was accomplished. The soil samples were collected from the depth of $0-20 \mathrm{~cm}$ using auger. Five samples (in zigzag pattern) were collected before land preparation and after harvesting to form composite soil samples (45), which has been transported to the laboratory for further processing. Plant roots and shoots were handpicked and discarded. Then soil samples were air dried, mixed well before analyses. Likewise, soil $\mathrm{pH}$ was measured in ratio of soil to water (1:2.5), using $\mathrm{pH}$ meter whereas Ec was measured by conductivity meter using suspension of 1:5 soil: water ratio. Organic carbon was determined by following [11]. Then, percent soil organic matter was calculated by multiplying the percent organic carbon by a factor of 1.724 . Total Nitrogen (TN) was determined by the micro-Kjeldahl digestion, distillation and titration method [12]. Available phosphorus (AP) was determined using the standard Bray II and Olsen test based on the results of $\mathrm{pH}$ [13] [14]. Finally, exchangeable potassium was determined using flame photometer [15].

\subsection{Data Analysis}

All data collected were subjected to Paired Sample T-test using IBM SPSS 20. Significance differences between treatments were delineated by LSD (Least Significant Difference) test at $5 \%$ level of significance.

\section{Result and Discussion}

\section{Effect of Planting Methods, Tied Ridge and Cropping System on Soil Chemical Properties}

1) Soil $\mathrm{pH}$

Soil $\mathrm{pH}$ was significantly different due to interaction of maize-haricot bean 
intercropping with both tied ridge and planting methods. Thus the maximum mean of soil $\mathrm{pH}$ was observed before planting at sole haricotbean with flat bed whereas the minimum soil $\mathrm{pH}$ were observed after planting of maize-haricot bean intercropping with closed end tied ridge and in furrow planting. When before and after planting values of $\mathrm{pH}$ was compared by $\mathrm{t}$-test it was indicated that there was reduction due to influence of maize-haricot bean intercropping (Table 1). Relatively lower $\mathrm{pH}$ values in the soil after planting due to maize-haricot bean intercropping with tied ridge and planting methods as compared to those sole maize and haricot bean, might be due to depletion of basic cations by the harvested crop biomass, leaching and phosphorus fixation. [16] has also reported that a lower $\mathrm{pH}$ value in intercropping land was attributed to a high rate of organic matter oxidation. This is important to produce organic acids and provide $\mathrm{H}+$ to the soil solution, and thereby reduces soil $\mathrm{pH}$ values.

2) Available Potassium

Intercropping of maize-haricotbean with tied ridge and planting methods were highly influenced available potassium in soil which is easily uptake by the crop. So that the mean of available potassium was significantly different due to interaction of maize-haricotbean intercropping with both tied ridge and planting methods. Likely available potassium in the soil was increased after planting due to maize-haricotbean intercropping (Table 1). Similarly, it was observed that by [17] $\mathrm{K}$ levels can be maintained when haricot-bean is grown in intercropping

Table 1. Effects of interaction of maize-haricotbean intercropping on soil fertility with tied ridge, cropping system and planting methods.

\begin{tabular}{|c|c|c|c|c|c|c|c|c|c|c|c|c|c|c|c|}
\hline $\mathrm{CS}^{*} \mathrm{TR}^{\star} \mathrm{PM}$ & & $\mathrm{pH}$ & & & Av.K & & Av & & & & $\% \mathrm{OM}$ & & & TN & \\
\hline & $\mathrm{BEF}$ & $\mathrm{AF}$ & t-test & $\mathrm{BEF}$ & $\mathrm{AF}$ & t-test & $\mathrm{BEF}$ & $\mathrm{AF}$ & t-test & $\mathrm{BEF}$ & $\mathrm{AF}$ & t-test & $\mathrm{BEF}$ & $\mathrm{AF}$ & $\mathrm{t}$-test \\
\hline $\mathrm{IC}^{\star} \mathrm{CE}^{\star} \mathrm{IF}$ & 6.04 & 5.09 & 0.032 & 2.21 & 3.87 & 0.036 & 4.03 & 7.42 & 0.011 & 5.25 & 9.06 & 0.002 & 0.22 & 0.41 & 0.025 \\
\hline $\mathrm{IC}^{*} \mathrm{CE}^{\star} \mathrm{OR}$ & 6.01 & 5.13 & 0.002 & 2.07 & 3.13 & 0.007 & 3.74 & 6.58 & 0.002 & 4.86 & 8.33 & 0.018 & 0.22 & 0.36 & 0.004 \\
\hline $\mathrm{IC}^{\star} \mathrm{OE}^{\star} \mathrm{IF}$ & 6.06 & 5.18 & 0.008 & 1.92 & 3.29 & 0.004 & 4.33 & 6.19 & 0.002 & 5.33 & 6.78 & 0.248 & 0.22 & 0.36 & 0.005 \\
\hline $\mathrm{IC}^{*} \mathrm{OE}^{\star} \mathrm{OR}$ & 5.93 & 5.41 & 0.006 & 2.1 & 2.9 & 0.005 & 3.68 & 5.77 & 0.014 & 5.97 & 7.05 & 0.017 & 0.21 & 0.31 & 0.029 \\
\hline $\mathrm{IC}^{*} \mathrm{FB}^{*} \mathrm{NO}$ & 5.90 & 5.53 & 0.154 & 2.15 & 2.46 & 0.178 & 3.75 & 4.97 & 0.002 & 5.37 & 6.14 & 0.602 & 0.21 & 0.26 & 0.184 \\
\hline $\mathrm{SM}^{*} \mathrm{CE}^{\star} \mathrm{OR}$ & 5.89 & 5.11 & 0.022 & 2.24 & 2.59 & 0.079 & 3.65 & 3.38 & 0.877 & 4.71 & 6.36 & 0.202 & 0.22 & 0.24 & 0.44 \\
\hline $\mathrm{SM}^{*} \mathrm{FB}^{*} \mathrm{NO}$ & 6.04 & 6.15 & 0.711 & 2.16 & 2.12 & 0.020 & 4.07 & 3.78 & 0.056 & 4.27 & 3.98 & 0.135 & 0.22 & 0.24 & 0.817 \\
\hline $\mathrm{SM}^{\star} \mathrm{OE}^{\star} \mathrm{OR}$ & 5.89 & 5.69 & 0.052 & 2.03 & 2.29 & 0.074 & 4.18 & 4.57 & 0.573 & 4.56 & 4.25 & 0.604 & 0.21 & 0.24 & 0.095 \\
\hline $\mathrm{SM}^{\star} \mathrm{OE}^{\star} \mathrm{IF}$ & 5.76 & 5.49 & 0.258 & 2.11 & 2.56 & 0.033 & 4.21 & 4.75 & 0.017 & 5.03 & 6.28 & 0.223 & 0.21 & 0.24 & 0.250 \\
\hline $\mathrm{SM}^{*} \mathrm{CE}^{\star} \mathrm{IF}$ & 6.02 & 5.58 & 0.025 & 2.00 & 2.69 & 0.008 & 3.37 & 4.97 & 0.009 & 4.49 & 6.82 & 0.035 & 0.22 & 0.21 & 0.338 \\
\hline $\mathrm{SH}^{\star} \mathrm{OE}^{\star} \mathrm{OR}$ & 5.78 & 5.81 & 0.423 & 2.14 & 2.37 & 0.423 & 3.65 & 3.88 & 0.423 & 5.79 & 6.19 & 0.423 & 0.22 & 0.24 & 0.423 \\
\hline $\mathrm{SH}^{*} \mathrm{OE}^{\star} \mathrm{IF}$ & 5.99 & 5.71 & 0.423 & 2.26 & 2.18 & 0.423 & 3.89 & 4.04 & 0.423 & 5.48 & 5.64 & 0.423 & 0.22 & 0.22 & 0.423 \\
\hline $\mathrm{SH}^{*} \mathrm{FB}^{\star} \mathrm{NO}$ & 6.28 & 6.24 & 0.423 & 2.11 & 2.12 & 0.423 & 3.69 & 3.91 & 0.423 & 4.95 & 4.99 & 0.423 & 0.21 & 0.20 & 0.423 \\
\hline $\mathrm{SH}^{*} \mathrm{CE}^{\star} \mathrm{OR}$ & 5.92 & 6.14 & 0.423 & 2.15 & 2.24 & 0.423 & 4.10 & 3.74 & 0.423 & 5.69 & 5.41 & 0.423 & 0.22 & 0.22 & 0.423 \\
\hline $\mathrm{SH}^{*} \mathrm{CE}^{*} \mathrm{IF}$ & 5.88 & 5.89 & 0.423 & 2.18 & 2.16 & 0.423 & 4.02 & 3.97 & 0.423 & 4.76 & 5.33 & 0.423 & 0.23 & 0.22 & 0.423 \\
\hline
\end{tabular}


with cereals. Results obtained by [18] at Kadawa, Kano clearly indicated that under continuous cultivation with intercropping of maize-haricotbean the available $\mathrm{K}$ can be improved.

3) Available Phosphorus

Comparison AP, before and after planting, was significantly different $(\mathrm{P} \leq$ 0.05 ) under interaction of maize with tied ridge and planting methods (Table 1). Therefore the values of available phosphorus was increased due to intercropping and available soil moisture Reduction of AP could be related to degree of its fixation which occurs at low $\mathrm{pH}$ levels where iron and aluminum activity actually increases [19].

4) Soil Organic Matter

On plot maize-haricot bean intercropping with tied ridge and planting methods soil organic matter was significantly different (LSD0.05) by their interaction effect. The highest amount of soil organic matter (9.06\%) was observed after planting; under maize-haricotbean intercropping with closed end tied ridge and in furrow planting whereas the minimum (4.27\%) were observed before planting at sole maize planting on flat bed (Table 1). This result was in line with [20] that reported the amount $f$ soil organic matter can alter rapidly and drastically as a consequence of legumes-cereals intercropping. In addition, [21] were obtained availability of soil moisture in arid and semi arid environment improved decomposition of organic matter by $20 \%$ in comparison to low temperature areas. These authors support the result of this research because high organic matter observed under closed tied ridge and in furrow planting. Similarly, [22] reported that intercropping cereals with legumes can address losses of soil organic matter in tropical, rainfed, low-input systems.

5) Total Nitrogen

Before and after planting total soil nitrogen was significantly different by interaction of maize-haricotbean intercropping with both tied ridge and planting methods. This might be because of legumes have capability to fix atmospheric-N through symbiosis (Table 1). It was agreed with works of [23] that reports, cereal-legumes intercropping patterns' effect on total soil $\mathrm{N}$ as significant. Likewise, [17] reports legume is grown in a mixture with a cereal, it can improve the $\mathrm{N}$ economy of the cereals both by contributing $\mathrm{N}$ to the soil for uptake by the cereal or simply by the legume removing less $\mathrm{N}$ than if the cereal was grown as a pure stand. Similarly, [24] were observed amount of mineral-N remaining in the soil after cereal-legume intercropping was greater than that after planting of non-legume crop with an equal amount of $\mathrm{N}$ in harvest products. This was might be because of legumes can satisfy part of its $\mathrm{N}$-requirement through atmospheric N-fixation. Likely, [25] also quantified N-savings on the order of 18 to $23 \mathrm{~kg} \mathrm{~N}$ per ha by Maize-haricotbean intercropping when compared with sole maize. Accordingly, biological nitrogen fixation is the major source of nitrogen in legume-cereal mixed cropping systems when nitrogen fertilizer is limited [26]. In addition, roots of the legume component can decompose and release nitrogen into the soil where it made available to subsequent crops. 
6) Water Use Efficiency

The crop yield and soil fertility status was significantly different (P0.05\%) due to tied ridge with intercropping of maize-haricotbean than tied ridge with sole maize and flat bed. Specifically, under closed end tied ridge this difference was mostly observed. This might be because of tied ridge was used as in-situ soil moisture conservation and maize used as a shade to haricotbean from direct sunlight intensity (Table 1). Likely, haricotbean was used as life mulching that can be reduced evaporation from the soil whereas maize was improved haricotbean water use efficiency by minimizing transpiration. The finding reported by [27] indicates that the advantage of the maize-haricotbean intercropping system under tied ridge is reflected in the water use and the water use efficiency value. The same authors were reported, in 1986 these crops together used $597 \mathrm{~mm}$ as opposed to $374 \mathrm{~mm}$ for the sole crop of maize and in 1987 total water used by maize and haricotbean in intercropping was $585 \mathrm{~mm}$, in contrast to $398 \mathrm{~mm}$ by the sole crop maize.

\section{Conclusions and Recommendation}

Soil $\mathrm{pH}$ was significantly different due to interaction of maize-haricot bean intercropping with both tied ridge and planting methods. Intercropping of maizeharicotbean with tied ridge and planting methods were highly influenced available potassium in soil which is easily absorbed by the crop. Available phosphorus, before and after planting, was significantly different $(\mathrm{P} \leq 0.05)$ under interaction of maize with tied ridge and planting methods. The highest amount of soil organic matter (9.06\%) was observed after planting; under maize-haricotbean intercropping with closed end tied ridge and in furrow planting whereas the minimum (4.27\%) were observed before planting at sole maize planting on flat bed.

Before and after planting total soil nitrogen was significantly different by interaction of maize-haricotbean intercropping with both tied ridge and planting methods. The soil fertility status was significantly different (P0.05\%) due to tied ridge with intercropping of maize-haricotbean than tied ridge with sole maize and flat bed. Specifically, under closed end tied ridge this difference was mostly observed.

Therefore, the use of intercropping and closed end tied ridge in combination with in furrow planting significantly increased soil fertility in the system, which could be promising for sustainable improvement of crop production and productivity for semi arid areas of Bale zone.

\section{References}

[1] Ladha, J.K., Pathak, H., Tirol-Padre, A., Dawe, D. and Gupta, R.K. (2003) Productivity Trends in Intensive Rice-Wheat Cropping Systems in Asia. In: Improving the Productivity and Sustainability of Rice-Wheat Systems. Issues and Impacts, ASA Special Publication 65, 45-76. https://doi.org/10.2134/asaspecpub65.c3

[2] Masto, R.E., Chhonkar, P.K., Singh, D. and Patra, A.K. (2008) Alternative Soil Quality Indices for Evaluating the Effect of Intensive Cropping, Fertilisation and 
Manuring for 31 Years in the Semi-Arid Soils of India. Environmental Monitoring and Assessment, 136, 419-435. https://doi.org/10.1007/s10661-007-9697-z

[3] Bouajila, K. and Sanaa, M. (2011) Effects of Organic Amendments on Soil PhysicoChemical and Biological Properties. Journal of Materials and Environmental Science, 2, 485-490.

[4] Darilek, J.L., Huang, B., Wang, Z., Qi, Y., Zhao, Y., Sun, W., Gu, Z. and Shi, X. (2009) Changes in Soil Fertility Parameters and the Environmental Effects in a Rapidly Developing Region of China. Agriculture, Ecosystems \& Environment 129, 286-292.

[5] Abebe, G. (2009) Effect of Np Fertilizer and Moisture Conservation on the Yield and Yield Components of Haricot Bean (Phaseolus Vulgaris L.) in the Semi Arid Zones of the Central Rift Valley in Ethiopia. Advances in Environmental Biology, 3, 302-307.

[6] Matusso, J., Mugwe, J. and Mucheru-Muna, M. (2014) Potential Role of CerealLegume Intercropping Systems in Integrated Soil Fertility Management in Smallholder Farming Systems of Sub-Saharan Africa. Journal of Agricultural and Environmental Management, 3, 162-174.

[7] Gebrekidan, H. (2003) Grain Yield Response of Sorghum (Sorghum Bicolor) to Tied Ridges and Planting Methods on Entosols and Vertisols of Haramaya Area, Eastern Ethiopian Highlands. Journal of Agriculture and Rural Development in the Tropics and Sub Tropics, 104, 113-128.

[8] Mekuria, M. and Waddington, S. (2004) Institutional and Policy Support Is Essential to Promote the Adoption of Soil Fertility Technologies on Maize-Based Smallholder Farms in Southern Africa. Proceedings of the 4th International Crop Science Congress, Brisbane.

[9] Kumar, A. and Rana, K.S. (2007) Performance of Pigeon Pea + Green Gram Intercropping System as Influenced by Moisture Conservation Practices and Fertility Level under Rain Fed Conditions. Indian Journal of Agronomy, 52, 31-35.

[10] Madda Walabu District of Finance \& Economic Development Office (MWDFEDO) (2009) Madda Walabu District Socio-Economic Profile. Bidire.

[11] Walkley, A. and Black, I.A. (1934) An Examination of Degtjareff Method for Determining Soil Organic Matter and a Proposed Modification of the Chromic Acid Titration Method. Soil Science, 37, 29-37. https://doi.org/10.1097/00010694-193401000-00003

[12] Bremner, J.M. and Mulvaney, C.S. (1982) Methods of Soil Analysis, Part 2 Chemical and Microbiological Properties. 595-624.

[13] Bray, R.H. and Kurtz, L.T. (1945) Determination of Total, Organic, and Available Forms of Phosphorus Is Soils. Soil Science, 59, 39-45. https://doi.org/10.1097/00010694-194501000-00006

[14] Olsen, S.R., Cole, C.V., Watanabe, F.S. and Dean, L.A. (1954) Estimation of Available Phosphorus in Soils by Extraction with Sodium Bicarbonate. US Department of Agriculture, Washington DC, Circular 939.

[15] Council (1999) Handbook on Reference Methods for Soil Analysis. Soil and Plant Analysis Council, Inc. CRC Press, Washington DC.

[16] Gebeyaw, T. (2007) Soil Fertility Status as Influenced by Different Land Uses in Maybar Areas of South Wello Zone, North Ethiopia. M.Sc. Thesis, Haramaya University, Ethiopia, 71. 
[17] Hamma, I.L. and Ibrahim, U. (2013) Management Practices for Improving Fertility Status of Soils in Nigeria. World Journal of Agricultural Sciences, 9, 271-276.

[18] Singh, L. and Nnadi, L.A. (1981) Residual Effect of Previous Crops and Fertilizers on Wheat Yield and Soil Properties at Kadawa. Nigeria Proceedings of 5 th NAFPP Working, Zaria, 26-30 April 1981, 83-91.

[19] Brady, N. and Weil, R. (2002) The Nature and Properties of Soils. 13th Edition, Prentice Hall, Upper Saddle River, 960 p.

[20] Hussein, M.Z., Tarmizi, R.S.H., Zainal, Z., Ibrahim, R. and Badri, R.M. (1996) Preparation and Characterization of Active Carbons from Oil Palm Shells. Carbon, 34, 1447-1453.

[21] Oso, B.A. and Ayodele, J.A. (1991) Potential of Water Hyacinth, Azolla and Other Weeds as Organic Fertilizer. Proceeding of a National Organic Fertilizer Seminar, Kaduna, 26-27 March 1991.

[22] Kumwenda, J.D.T., Waddington, S.R., Snapp, S.S., Jones, R.B. and Blackie, M.J. (1996) Soil Fertility Management Research for the Maize Cropping Systems of Smallholders in Southern Africa: A Review. NRG Paper 96-02. CIMMYT, Mexico.

[23] Wiqar Ahmad, A., Farmanullah, B., Zahir Shah, B., Muhammad, J.B. and Kawsar, A.S. (2013) Recovery of Organic Fertility in Degraded Soil through Fertilization and Crop Rotation. Journal of the Saudi Society of Agricultural Sciences, 13, 92-99.

[24] Fiego, T.J. and Seeling (1996) Long-Term Effects of Legume-Based Cropping Systems on Soil Nitrogen Status and Mineralization in Vertisols. International Crops Research Institute for the Semi-And Tropics, Patancheru.

[25] Senaratne, R. and Hardarson, G. (1988) Estimation of Residual N Effect of Fababean and Pea on Two Succeeding Cereals Using ${ }^{15} \mathrm{~N}$ Methodology. Plant and Soil, 110, 81-89. https://doi.org/10.1007/BF02143543

[26] Fujita, K., Ofosu-Budu, K.G. and Ogata, S. (1992) Biological Nitrogen Fixation in Mixed Legumecereal Cropping Systems. Plant Soil, 141, 155-176. https://doi.org/10.1007/BF00011315

[27] Sivakumar, M.V.K., Motha, R.P., Wilhite, D.A. and Qu, J.J. (2011) Towards a Compendium on National Drought Policy. Proceedings of an Expert Meeting, Washington DC, 14-15 July 2011, 135 p.

\section{Submit or recommend next manuscript to SCIRP and we will provide best service for you:}

Accepting pre-submission inquiries through Email, Facebook, LinkedIn, Twitter, etc.

A wide selection of journals (inclusive of 9 subjects, more than 200 journals)

Providing 24-hour high-quality service

User-friendly online submission system

Fair and swift peer-review system

Efficient typesetting and proofreading procedure

Display of the result of downloads and visits, as well as the number of cited articles

Maximum dissemination of your research work

Submit your manuscript at: http://papersubmission.scirp.org/

Or contact gep@scirp.org 